\title{
Effect of exclosure on dryland woody species restoration in northeastern Amhara, Ethiopia
}

\author{
Mubarek Eshetie ${ }^{1}$ Tsegaye Gobezie ${ }^{2}$. \\ Seid Muhie Dawd ${ }^{2}$
}

Received: 4 June 2020 / Accepted: 30 August 2020 / Published online: 19 November 2020

(C) The Author(s) 2020

\begin{abstract}
In Ethiopia, among many restoration efforts to reverse deforestation and land degradation, area exclosure is one of the most common practices to restore secondary forests with assisted natural regeneration. The present study in the Sekota district, northeastern Amhara region, Ethiopia evaluated the influence of areas exclosures on woody species diversity, population structure and regeneration status. A total of 36 and 27 quadrats, each $20 \mathrm{~m} \times 20 \mathrm{~m}$, were used to collect data in exclosures and non-exclosures, respectively. Within quadrats, four $5 \mathrm{~m} \times 5 \mathrm{~m}$ and $2 \mathrm{~m} \times 2 \mathrm{~m}$ quadrats at the corners were used to sample saplings and seedlings, respectively. In exclosures, 35 woody species representing 21 families and 29 genera were recorded; 19 woody species representing 13 families and 13 genera were recorded in the
\end{abstract}

Project Funding: This work was supported financially by the the Sekota Dry Land Agricultural Research Center/Amhara Region Agricultural Research Institute (ARARI).

The online version is available at http://www.springerlink.com.

Corresponding editor: Zhu Hong.

Electronic supplementary material The online version of this article (https://doi.org/10.1007/s11676-020-01248-x) contains supplementary material, which is available to authorized users.

Mubarek Eshetie

eshete99@gmail.com

Tsegaye Gobezie

tsegaye_gobezie@yahoo.com

Seid Muhie Dawd

seid.muhie@wu.edu.et

1 Sekota Dryland Agricultural Research Center, P.O. Box 62, Sekota, Ethiopia

2 Department of Forestry, College of Agriculture, Wollo University, P.O.Box 1145, Dessie, Ethiopia non-exclosure. Acacia etbaica was the most dominant species in the two land-uses. The Shannon diversity index was $1.77 \pm 0.46$ in exclosures and $1.39 \pm 0.46$ in non-exclosures. Shannon and Simpson diversity indices showed a significant difference between the two land-uses $(p<0.01)$. The regeneration status of all wood species in exclosures was good, only fair in non-exclosures. Area exclosures have thus played a great role in the restoration of degraded lands by improving vegetation diversity and regeneration status. The least dominant woody species should be maintained through active restoration. Continuous follow-up, maintenance of soil water conservation structure to improve soil fertility will further help enhance the woody species diversity and abundance.

Keywords Restoration - Diversity · Regeneration status · Exclosure

\section{Introduction}

Land degradation is a widespread serious threat to the livelihoods of $250 \times 10^{6}$ people residing in drylands (Yirdaw et al. 2017), where an estimated $12 \times 10^{6}$ ha are degraded each year (James et al. 2013; Yirdaw et al. 2017). Deforestation in Ethiopia has been a major land degradation problem for the past three millennia with severe ecological and socioeconomic consequences (Birhane et al. 2007; Yirdaw et al. 2014).

Several global initiatives have been launched against land degradation, including rehabilitation of degraded drylands (Yirdaw et al. 2017), including many efforts to reverse deforestation and land degradation in Ethiopia (Ubuy et al. 2018). Area exclosure, hereafter "exclosure", is a land management practice whereby livestock and humans are excluded 
from openly accessing a severely degraded area (Aerts et al. 2009). Exclosures are advantageous over other methods such as hillside terracing and planting; it is fast and inexpensive, relatively easy, requires less investment in planting materials, site preparation and management (Birhane et al. 2017), and existing vegetative material may invade the site faster and with better coverage than planted seedlings. They are implemented for management or research purposes (Ubuy et al. 2014) to improve degraded and generally open-access lands (Birhane et al. 2007; Mekuria 2007) and to prevent agricultural use (Mekuria et al. 2009). Not only do they help restore native woody plants (Aerts et al. 2009; Ubuy et al. 2014), they also help control soil erosion (Mekuria et al. 2009) and improve soil fertility (Mekuria 2013a).

In Ethiopia today, exclosure is one of the most widespread practices for re-greening (Lemenih and Kassa 2014) and restoring secondary forests with assisted natural regeneration. By the end of 2013, exclosures in Ethiopia had been established on 3 million hectares (1.55 million hectares in the Amhara region in northeastern Ethiopia) (Lemenih and Kassa 2014), and are now common in northern Ethiopia to fight land degradation and restore species composition and diversity (Descheemaeker et al. 2006; Yayneshet et al. 2009).

When an exclosure is established to improve the overall ecological condition of an area, the initial woody species diversity needs to be quantified and evaluated to understand the restoration potential of the woody species in the exclosure, and provide a good database to aid the design of management measures in the exclosure (Naidu and Kumar 2016). This information is also used to develop a comprehensive approach to conserve important but less-dominant woody species and enhance the regeneration capacity of dominant woody species to maintain the ecological balance in the exclosure (Naidu and Kumar 2016). The present study compared the effect of exclosure and non-exclosure on woody species restoration, diversity, population structure, and regeneration status at the three sites in northeastern Ethiopia.

\section{Materials and methods}

\section{Study area}

The study sites in Sekota district, northeastern Amhara, Ethiopia were located at $12^{\circ} 41^{\prime} \mathrm{N}, 12^{\circ} 31^{\prime} \mathrm{N}$ and $12^{\circ} 42^{\prime} \mathrm{N} / 39^{\circ} 01^{\prime} \mathrm{E}$ for Gateno and Mildam, Jinqaba, respectively. The altitudinal range of the study sitesis about 1340-2220 m a.s.l. (Figure 1). The mean annual temperature ranges from 11.2 to $29.1{ }^{\circ} \mathrm{C}$. The rainfall pattern is unimodal with an annual rainfall of 300-653 $\mathrm{mm}$ have been recorded for 23 years (1996-2017) at Aybra Meteorological Station (NMSA

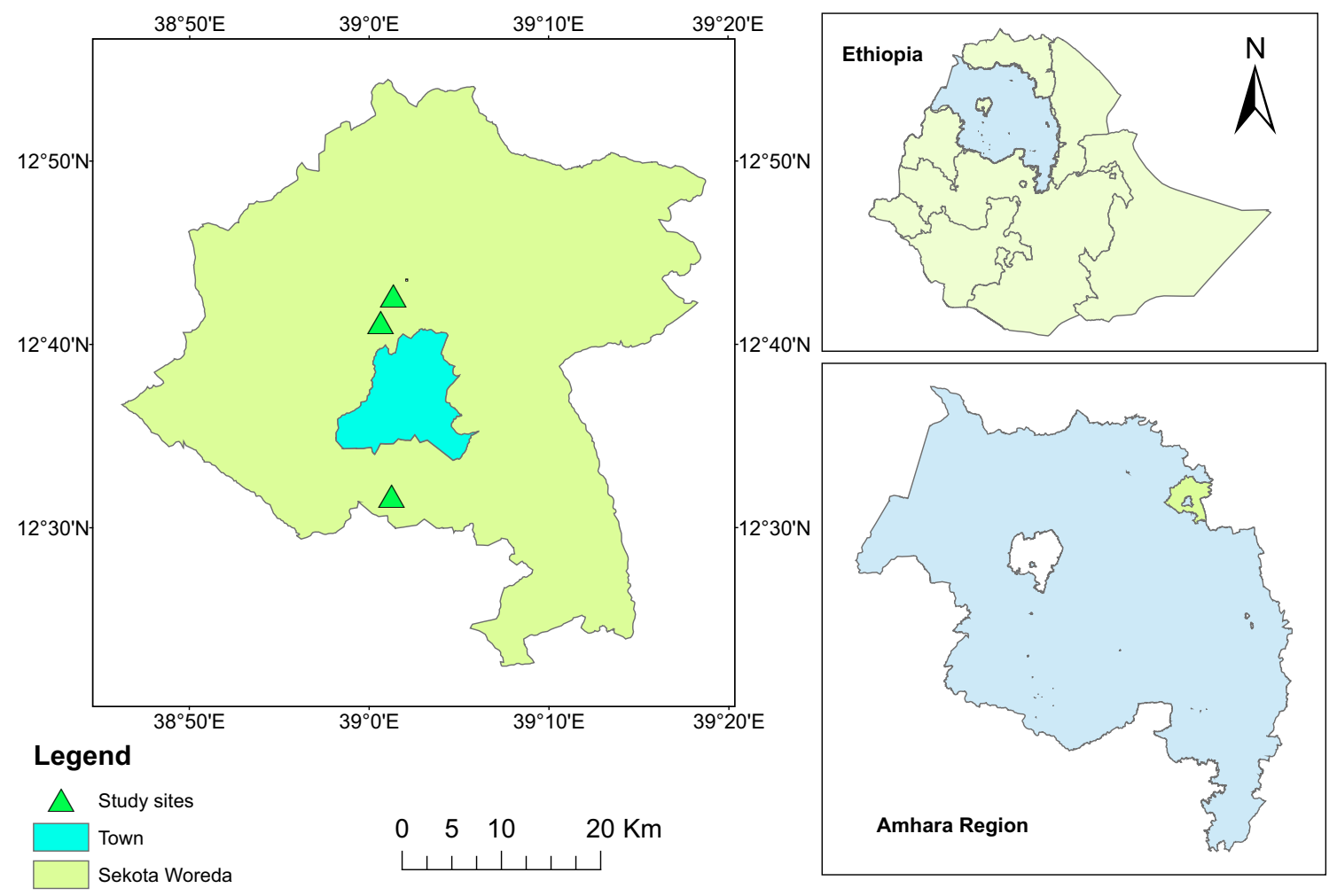

Fig. 1 Map showing the location of the three study sites in Ethiopia 
2017). Rainfall is concentrated in between June and August; the other 9 months are considered dry.

The vegetation around the Sekota districts could be categorized as dry evergreen afromontane forest with several dominant species such as Acacia etbaica, Acacia abyssinica, Acacia albida, Acacia seyal, Acacia tortilis, Dodonaea angustifolia, Erythrina abyssinica, Euphorbia candelabrum, and Olea africana. Broad-leaved Fabaceae species dominate in the Sekota districts (Mengistu et al. 2005). The soil in the study sites is generally infertile, coarse-textured, and sandy.

\section{Sampling methods}

Three exclosures (Gateno, Mildam, and Jinqaba) were selected based on their comparable management level, soil, climate (Mengistu et al. 2005; Mekuria 2007) and accessibility. All exclosures were 10 years old and were previously open grazing lands. Soil and water conservation structures, such as half-moon, soil and stone bunds had been set up in the exclosures, and free grazing or browsing was not allowed. However, the non-exclosure had no soil or water conservation structures and were open for grazing or browsing. The area coverage of the exclosure was 16.34 ha for Gateno, 15.4 ha for Mildam and 12.2 ha for Jinqaba. In each exclosure, an adjacent non-exclosure (grazing lands) was selected to have paired exclosure and non-exclosure sites to understand how changes in land-use have influenced woody species diversity and abundance (Mekuria et al. 2018).

Quadrats and transect lines were laid with a maximum interval of distance of $100 \mathrm{~m}$ and $250 \mathrm{~m}$, respectively, for the two land-uses. Three transect lines were laid in each selected exclosure and non-exclosure sites. The number of quadrats was determined based on vegetation density, spatial heterogeneity of vegetation, and area of the site (Mengistu et al. 2005). The number of quadrats placed was proportional to the area coverage and vegetation density; 15 plots were set up for Gateno, 12 for Mildam and 9 for Jinqaba. A total of 36 and 27 square quadrats were set up in exclosure and nonexclosure, respectively. The initial quadrat in all transects was laid out $50 \mathrm{~m}$ from the inside edge of the exclosures and non-exclosures to avoid edge effects; subsequent quadrats were arranged systematically (Mekuria and Aynekulu 2013).

Along each transect, sample quadrats (main quadrats) measuring $20 \mathrm{~m} \times 20 \mathrm{~m}\left(400 \mathrm{~m}^{2}\right)$ were laid out to sample trees (Fig. 2). In each main quadrat, a subplot was placed in each corner, each with a subquadrat of $5 \mathrm{~m} \times 5 \mathrm{~m}$ to sample saplings and $2 \mathrm{~m} \times 2 \mathrm{~m}$ for seedling (Birhane et al. 2007).

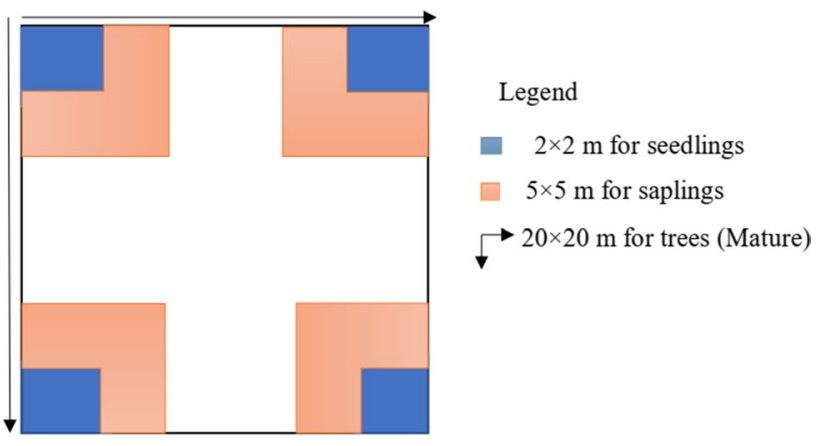

Fig. 2 Diagram of the sampling areas inside each $20 \times 20 \mathrm{~m}$ main quadrat set up for exclosure and non-exclosure sites

\section{Data collection}

The diameter and height of individuals of woody species were measured using a caliper and graduated wooden pole, respectively. The diameter was measured at the soil surface (basal stem diameter), at $0.7 \mathrm{~m}$ for saplings and $1.3 \mathrm{~m}$ (breast height) for mature trees or shrubs. Individuals were then grouped into height classes $<1.5 \mathrm{~m}$ (seedlings), $1.5-3 \mathrm{~m}$ (saplings), and $>3 \mathrm{~m}$ (trees) and diameter classes of $<2.5 \mathrm{~cm}$ (seedlings), $2.5-5 \mathrm{~cm}$ (saplings) and $>5 \mathrm{~cm}$ (trees). In each plot, all woody species were identified based on published floras for Ethiopia (Edwards et al. 1969, 1995, 1997; Hedberg and Edwards 1989; Hedberg et al. 2003, 2006) and recorded.

\section{Data analyses}

\section{Woody species diversity and evenness}

Species richness, i.e., the total number of species in a sample area, is very sensitive to the number of individuals (Gotelli and Chao 2013). An increase in species richness does not mean an increase in species diversity. Species richness also does not measure the evenness of the species abundance distribution (Gotelli and Chao 2013). The diversity of woody species was analyzed using the Shannon diversity index $\left(H^{\prime}\right)$ (Shannon and Weiner 1963), which gives more weight to rare species, and the Simpson diversity index (D) (Simpson 1949), which gives more weight to the most dominant species in a sample (Magurran 2004). Sorensen's coefficient of similarity was used to compute similarity in the composition of woody species between exclosure and non-exclosure (Kent and Cooker 1992). Non-metric multidimensional scaling (NMDS) based on Bray-Curtis dissimilarity was used to visualize and evaluate patterns of dissimilarity within exclosure and non-exclosure species composition. Permutational 
multivariate analyses of variance (PERMANOVA) (Anderson 2001) was used to test the differences in species composition between exclosure and non-exclosure.

\section{Structural data analyses}

The diameter at breast height and height of the woody plants were used for a horizontal and vertical structure analysis. The stand structure was expressed in terms of species abundance, frequency, density, dominance, and importance value index (IVI). To understand the population structure of woody individuals and some important woody species, we constructed a histogram using the frequency distribution of diameter and height classes of the arbitrary classes (Birhane et al. 2007). The number of seedlings, saplings and mature or adult woody individuals were counted and compared to assess the regeneration potential of exclosures and non-exclosures.

\section{Statistical analyses}

The differences between land-use types for each site or differences among sites for each land-use were tested using linear mixed effect models with land-use as the fixed effect and site or replicate plots as random effects. The statistical significance for all the tests was set at $P \leq 0.05$. All analyses were conducted using $\mathrm{R}$ version 4.0.2 (R Core Team, R Foundation for Statistical Computing, Vienna, Austria), and Statistical Package for Social Science (SPSS version 22; IBM, Armonk, NY, USA).

\section{Results}

\section{Species-accumulation curve for exclosure and non-exclosure}

The species-accumulation curve for the exclosure displayed a sharper increase initially to plot 16 and then remained flat into plot 28. After plot 29, the number of species increased until it flattened from plot 33 on. In the non-exclosure, the curve initially rose, then flattened after plot 6 . Then, after plot 20 the number of species increased and remains flat. Therefore, the graph showed that sample quadrats were sufficient and could give information about woody species indicators in the two land-uses (Fig. 3).

\section{Species composition and abundance}

PERMANOVA results indicated that the species composition significantly differed among the land-uses $(F=6.37$, $P<0.001)$. Grewia viscosa, Ormocarpumt trachycarpum, and A. etbaica were selected based on their higher regression

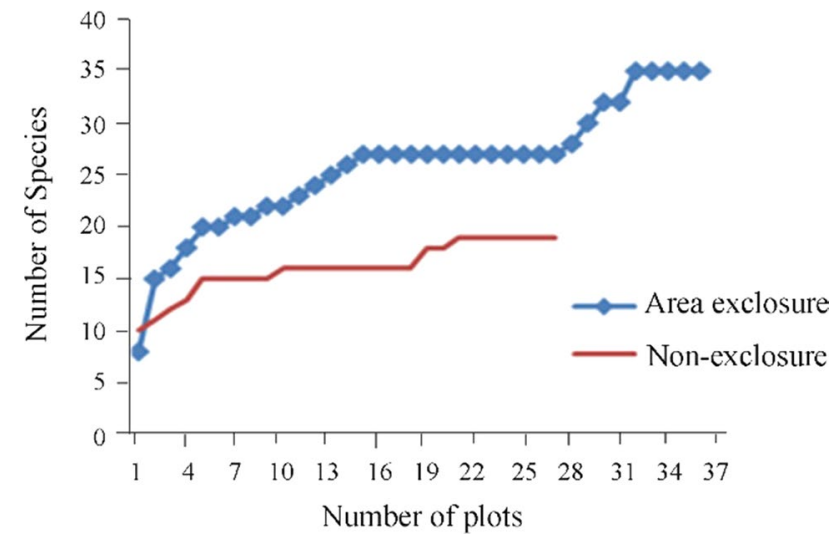

Fig. 3 Species-accumulation curve for the exclosure and non-exclosure

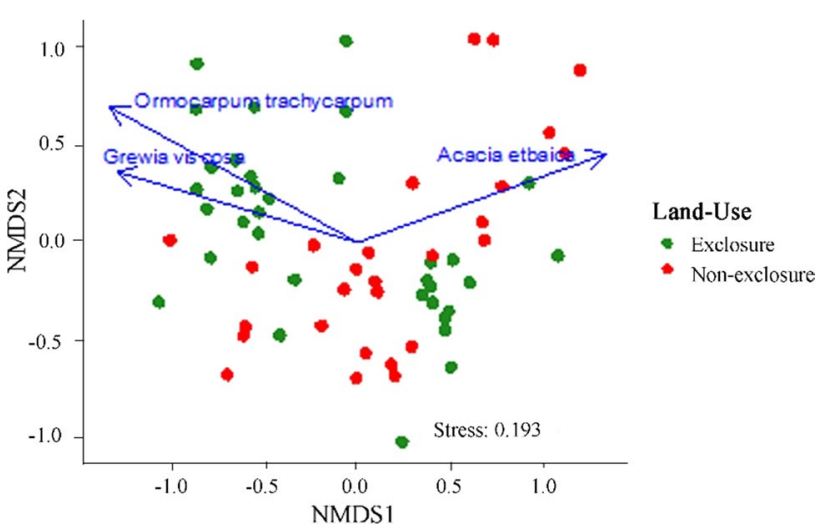

Fig. 4 Nonmetric multidimensional scaling based on Bray-Curtis dissimilarities for exclosure and non-exclosure. Arrows indicate significant correlations and the lengths of arrows are relative to the strength of the correlation

coefficient value. The abundance of G. viscosa and O. trachycarpum was significantly correlated with exclosure species composition $(P<0.001)$. Acacia etbaica was significantly correlated with exclosure and non-exclosure species composition $(P<0.001)$ (Fig. 4).

A total of 36 woody species belonging to 21 families and 29 genera were recorded in exclosure and non-exclosure. In the exclosure, a total of 35 woody species belonging to 21 families and 29 genera were recorded. In the non-exclosure, 19 woody species representing 13 families and 16 genera were recorded. Eighteen woody species were recorded both in exclosure and non-exclosure, while 17 species and 1 species were found only in exclosure and non-exclosure, respectively (Tables S1, S2).

The abundance of woody species range varied from 1 (Cordia africana and Calpurnia aurea) to 1030 (A. etbaica) in the exclosure. In the non-exclosure, abundance ranged from 1 (E. abyssinica) to 384 (A. etbaica) (Tables S1, S2). 
Based on Sorensen's coefficient of similarity index, the similarity of woody species between the exclosure and nonexclosure was $41 \%$.

\section{Density, frequency, basal area and importance value index (IVI)}

Stem density, height and basal area of woody species differed significantly between land-uses at each site. Heights at the Gateno exclosure differed significantly from those at the Milldam and the Jinqaba exclosures. However, there were no significant differences in density, frequency and basal area among non-exclosures at the three sites (Table 1). The mean density of woody species varied from 0.75 to 715.25 for exclosure and 1 to 355.5 for non-exclosure at the species level (Tables S1, S2).

In the exclosures, the highest frequency was recorded for A. etbaica, followed by Rhus vulgaris and Euclea racemosa subsp. schimperi. Calpurnia aurea, Cordia africana, and Grewia bicolor occurred in only one plot, and its frequency was lower (2.78\%) (Tables S1, S2). In the non-exclosures, $A$. etbaica, Cassia didymobotrya, and $R$. vulgaris occurred frequently and E. abyssinica, Combretum molle, and Dichrostachys cinerea less frequently.

Acacia etbaica, Euclea racemosa subsp. schimperi, and Opuntia ficus indica scored high for basal area $\left(\mathrm{m}^{2} / \mathrm{ha}\right)$ in exclosures, and G. bicolor, C. aurea, and C. africana had lower basal area (Tables S1, S2). In non-exclosures, $A$. etbaica, Euphorbia candelabrum, and A. tortilis had higher basal area, and Ormocarpum trachycarpum, D. cinerea, and Stereospermum kunthianum had lower basal area.
Importance value index indicated that, A. etbaica, $E$. racemosa subsp. schimperi, D. angustifolia, and $R$. vulgaris were the most dominant woody species and Buddleja polystachya, G. bicolor, C. aurea, and C. africana the least dominant species in the exclosures (Table S1). In the nonexclosures, A. etbaica, E. candelabrum, $R$. vulgaris, and $C$. didymobotrya were the most dominant woody species and C. molle, D. cinerea, E. abyssinica, and S. kunthianum the least dominant (Table S2).

\section{Richness, evenness and diversity of woody species}

Shannon and Simpson diversity indices and richness of woody species differed significantly between the two landuses at each site. However, Shannon evenness did not differ significantly between the two land-uses. Shannon and Simpson diversity and species richness at Gateno (exclosure and non-exclosure) differed significantly between the Milldam and the Jinqaba sites (exclosures and non-exclosures) (Table 2).

\section{Horizontal and vertical structure and regeneration status}

In the exclosures, the horizontal structure of A. etbaica, $D$. angustifolia, and $R$. vulgaris had an inverted J-shape, and E. racemosa subsp. schimperi had a bell shape. In the nonexclosure, E. racemosa subsp. schimperi and $R$. vulgaris, and $D$. angustifolia had a bell shape and irregular shape, respectively (Figs. S1, 2). In addition, seedlings (45\%) were more numerous than saplings (43\%) and trees (12\%) in the exclosures. More saplings (49\%) than seedlings (39\%) and trees (12\%) were found in the non-exclosures (Fig. S3).
Table 1 Mean $( \pm$ standard deviation) density, height and basal area of woody species from exclosures and nonexclosures within each site

\begin{tabular}{lcccc}
\hline Land-use/site & No. of species & Density (Individuals/ha) & Height $(\mathrm{m})$ & Basal area $\left(\mathrm{m}^{2} / \mathrm{ha}\right)$ \\
\hline Gateno & & & & \\
Exclosure & 9 & $161.12 \pm 45.24^{\mathrm{Aa}}$ & $1.93 \pm 0.29^{\mathrm{Ab}}$ & $0.037 \pm 0.013^{\mathrm{Aa}}$ \\
Non-exclosure & 5 & $105.89 \pm 40.23^{\mathrm{Ba}}$ & $2.06 \pm 0.37^{\mathrm{Ba}}$ & $0.030 \pm 0.014^{\mathrm{Ba}}$ \\
Mildam & & $142.73 \pm 52.34^{\mathrm{Aa}}$ & $2.41 \pm 0.49^{\mathrm{Aa}}$ & $0.040 \pm 0.007^{\mathrm{Aa}}$ \\
Exclosure & 17 & $73.14 \pm 23.93^{\mathrm{Ba}}$ & $2.07 \pm 0.40^{\mathrm{Ba}}$ & $0.032 \pm 0.012^{\mathrm{Ba}}$ \\
Non-exclosure & 10 & & & \\
Jinqaba & & $168.52 \pm 59.58^{\mathrm{Aa}}$ & $2.36 \pm 0.29^{\mathrm{Aa}}$ & $0.066 \pm 0.062^{\mathrm{Aa}}$ \\
Exclosure & 17 & $89.82 \pm 39.06^{\mathrm{Ba}}$ & $1.67 \pm 0.24^{\mathrm{Ba}}$ & $0.036 \pm 0.017^{\mathrm{Ba}}$ \\
Non-exclosure & 12 & & & \\
Total & & $156.84 \pm 51.01^{\mathrm{A}}$ & $2.20 \pm 0.42^{\mathrm{A}}$ & $0.045 \pm 0.033^{\mathrm{A}}$ \\
Exclosure & 35 & $89.62 \pm 36.46^{\mathrm{B}}$ & $1.94 \pm 0.37^{\mathrm{B}}$ & $0.033 \pm 0.014^{\mathrm{B}}$ \\
Non-exclosure & 19 &
\end{tabular}

Notes Means followed by different capital letters indicate significant differences between land-use within each site; different lowercase letters indicate significant differences among the three sites within a land-use type (linear mixed effect models with Tukey's HSD at $P \leq 0.05$ ) 
Table 2 Mean ( \pm standard deviation) diversity, richness and evenness of woody species from exclosure and nonexclosure within each site

\begin{tabular}{lcccc}
\hline Land use/site & Shannon $\left(H^{\prime}\right)$ & Simpson $(1 / \mathrm{D})$ & Evenness & Richness \\
\hline Gateno & & & & \\
Exclosure & $1.41 \pm 0.44^{\mathrm{Ab}}$ & $3.55 \pm 1.40^{\mathrm{Ab}}$ & $0.72 \pm 0.18^{\mathrm{Ab}}$ & $6.87 \pm 1.60^{\mathrm{Ab}}$ \\
Non-exclosure & $0.73 \pm 0.45^{\mathrm{Bb}}$ & $1.51 \pm 0.44^{\mathrm{Bb}}$ & $0.59 \pm 0.21^{\mathrm{Bb}}$ & $2.89 \pm 0.1 .27^{\mathrm{Bb}}$ \\
Mildam & & & \\
Exclosure & $1.95 \pm 0.21^{\mathrm{Aa}}$ & $5.3 \pm 1.11^{\mathrm{Aa}}$ & $0.80 \pm 0.04^{\mathrm{Aab}}$ & $11.67 \pm 2.96^{\mathrm{Aa}}$ \\
Non-exclosure & $1.82 \pm 0.23^{\mathrm{Ba}}$ & $5.48 \pm 1.37^{\mathrm{Ba}}$ & $0.90 \pm 0.06^{\mathrm{Aa}}$ & $7.55 \pm 1.74^{\mathrm{Ba}}$ \\
Jinqaba & & & & \\
Exclosure & $2.11 \pm 0.33^{\mathrm{Aa}}$ & $6.78 \pm 2.03^{\mathrm{Aa}}$ & $0.85 \pm 0.05^{\mathrm{Aa}}$ & $12.67 \pm 3.77^{\mathrm{Aa}}$ \\
Non-exclosure & $1.61 \pm 0.25^{\mathrm{Ba}}$ & $4.47 \pm 1.34^{\mathrm{Ba}}$ & $0.83 \pm 0.06^{\mathrm{Aa}}$ & $7.22 \pm 2.04^{\mathrm{Ba}}$ \\
Total & & & & \\
Exclosure & $1.77 \pm 0.46^{\mathrm{A}}$ & $4.94 \pm 1.96^{\mathrm{A}}$ & $0.78 \pm 0.18^{\mathrm{A}}$ & $9.94 \pm 3.8^{\mathrm{A}}$ \\
Non-exclosure & $1.39 \pm 0.59^{\mathrm{B}}$ & $3.82 \pm 2.07^{\mathrm{B}}$ & $0.77 \pm 0.19^{\mathrm{A0} .77}$ & $5.96 \pm 2.71^{\mathrm{B}}$ \\
\hline
\end{tabular}

Notes Means followed by different capital letters indicate significant differences between land-use within each site; different lowercase letters indicate significant differences among the three sites within a land-use type (linear mixed effect models with Tukey's HSD at $P \leq 0.05$ )

\section{Discussion}

\section{Woody species composition and abundance}

The results revealed that the composition and abundance of woody species in the exclosures were higher than in the non-exclosures. In the exclosures, soil and water conservation structure, protection from illegal wood cutting, excluded from the animal intervention (trumping and overgrazing) have applied properly. This management could be contributing to increasing woody species composition and abundance and as well as may allowed rise seed bank in exclosure. Similarly, 38 woody species representing 17 families were found in 10-year exclosure in semiarid part of northern Ethiopia (Gebregerges et al. 2018). According to Teketay et al. (2018), the continuous anthropogenic disturbances (cutting of trees for fuelwood, construction, and annual humaninduced fires), heavy browsing, and overgrazing have a great contribution to decreasing of woody species composition in non-exclosures. This idea agrees with other findings from northern Ethiopia (Yayneshet et al. 2009; Mekuria 2013b; Gebrehiwot and Veen 2014), southern Ethiopia (Rift Valley) (Mohammed et al. 2015), northwestern Ethiopia (Mekuria et al. 2018).

\section{Density, frequency, basal area, and importance value index}

Acacia etbaica has higher density, frequency, and thus is the most dominant species in the two land-uses. In the study districts, this species is present in all land-uses (farmlands, around roads and homes, steep hills, and valleys). In the study exclosures, Euclea racemosa subsp. schimperi, D. angustifolia, and Rhus vulgaris were also frequently observed. Dodone angustifolia and A. etbaica in particular serve a pioneer species that start to germinate after exclosure. Acacia etbaica is a known pioneer species and more dominant in disturbed sites, taking advantage of primary succession (Birhane et al. 2006).

Cordia africana, Calpurnia aurea, and Grewia bicolor were present at lower density and frequency in exclosures than in non-exclosures. Cassia didymobotrya and E. racemosa subsp. schimperi were observed frequently in nonexclosures. The reason these species have higher density in non-exclosures is because they are unpalatable to livestock. According to Tessema et al. (2011) heavy grazing/browsing might reduce plant species density over time.

Basal area in the exclosures was higher than in the nonexclosures at each site. The difference in basal area between the exclosures and non-exclosures could be due to the high abundance of woody species in the exclosures. The greater difference in basal area between exclosures and non-exclosures could be due to the high number of multi-stemmed trees in the exclosures, leading to bigger diameters (Birhane et al. 2007).

Acacia etbaica, E. racemosa subsp. schimperi, D. angustifolia, and $R$. vulgaris are the most dominant woody species in the exclosures; A. etbaica, Euphorbia candelabrum, $C$. didymobotrya, and $R$. vulgaris are the most dominant species in the non-exclosures. The high basal area of A. etbaica and Euclea racemosa subsp. schimperi contributed to the higher IVI in the exclosures. However, the IVI of D. angustifolia increased due to an individual's density. On the other hand, the higher IVI of Euphorbia candelabrum was due to its large diameter. Similarly, Menigstu et al. (2005) and Birhane et al. (2006) reported that A. etbaica is a dominant woody species in northern Ethiopia.

The IVI is also used for prioritizing species conservation; species with a low IVI need high conservation priority compared to ones with high IVI (Zegeye et al. 2006). Over 
$28 \%$ of the IVI was recorded by A. etbaica, while most of the other woody species had lower IVI except some other dominant species. According to Kacholi (2014), the presence of many species with lower IVI values is an indication that the majority of species are rare. Schwarz et al. (2003) also suggested that the rarity of species may be due to such factors as a resource gradient, poor dispersal, and natural disturbances.

Dichrostachys cinerea, Combretum molle, and S. kunthianum were the least dominant species in the non-exclosures. Because the first two species are used for local construction and fencing materials, fuelwood, and animal forage and many parts of $C$. molle are used for medicinal and other purposes, they likely are more heavily used than the other woody species by humans or animals. In fact, studies in northern Ethiopia indicated that anthropogenic and animal impacts during maturity or early regeneration could be a sign of increased vulnerability of the plant species in nonexclosures (Yayneshet, et al. 2009; Gebrehiwot and Anne, 2014; Atsbha et al. 2019).

\section{Richness, evenness and diversity}

The richness and Shannon and Simpson diversity indices of woody species were higher in the exclosures than nonexclosures at each site, as did other studies in northern Ethiopia (Yayneshet et al. 2009; Mekuria and Aynekulu 2013; Mekuria 2013a, b) and in a 10-year exclosure compared with a non-exclosure in semi-arid northern Ethiopia (Gebregerges et al. 2018). However, the Shannon evenness was relatively similar for the two land-uses, indicating a balanced distribution of the individuals of woody species in the two land-uses.

\section{Stand structure and regeneration status}

Diameter at breast height (DBH) and height distribution in arbitrary classes can help determine the regeneration status of woody species (Senbeta and Teketay 2001). Different patterns of species population structure can indicate variation in population dynamics (Feyissa et al. 2013). Senbeta et al. (2014) categorized the regeneration status as 1 , good regeneration, if numbers are in the order seedlings $>$ saplings $>$ adults; 2 , fair regeneration, if seedlings $>$ or $<$ saplings $>$ or $<$ adults; 3 , poor regeneration, if the species survives only to the sapling stage or only the seedling stage (seedlings and saplings may number fewer, more or equal to the number of adults); 4, no regeneration, if a species is present only in adult form; 5 , reappearing, if the species has no adults, only seedlings or saplings.

Accordingly, in the exclosures, the horizontal structure of A. etbaica, D. angustifolia, $R$. vulgaris, and all wood species had an inverse $\mathrm{J}$-shape, indicating that woody species have good regeneration status in exclosures. However, $E$. racemosa subsp. schimperi has a bell-shaped population structure; thus, the intermediate-sized individuals were more numerous than seedlings and trees because this species could be more affected by natural disturbances than other woody species.

In the non-exclosures, woody species population structures were as inverted J-shape, bell shape, or irregular shape. A. etbaica with its inverted J-shaped distribution has a good regeneration status. The high number of individuals in the lower diameter classes and decreasing numbers of individuals in the higher diameter classes in northern Ethiopia was reported previously (Mengistu et al. 2005; Birhane et al. 2006; Birhane et al. 2007).

Euclea racemosa subsp. schimperi and $R$. vulgaris had bell-shaped curves and thus, a fair regeneration status more individuals in the middle class. Dodonea angustifolia with its irregular-shaped curve, had fewer individuals in class 1, more in the class 2 , then also fewer in class 3 . This species might be palatable to animals, and thus browse, graze or trample small-diameter individuals.

The vertical structure of some dominant species like $A$. etbaica, E. racemosa subsp. schimperi, and $R$. vulgaris in exclosures was grouped as having good regeneration and in non-exclosures as fair regeneration. In general, the horizontal and vertical regeneration status could not describe the regeneration potential of the species separately. Therefore, the regeneration status of all woody species could be described in terms of both horizontal and vertical structures. The regeneration status can be influenced by selective removal of small diameter class individuals and human disturbance, livestock trampling, or browsing, and other biotic and biotic factors in the non-exclosures, which might retard normal recruitment (Adamu et al. 2012; Teshager et al. 2018).

\section{Conclusion}

We determined woody species diversity, composition and abundance, population structure, and regeneration status in exclosures and non-exclosures at three sites. Exclosures had more woody species diversity, composition, and good regeneration status. In exclosures, land management and protection from human intervention could improve soil moisture and fertility, which consequently increase the woody species composition, abundance, diversity, and regeneration potential. The regeneration status of all woody species in the non-exclosures was categorized as fair which could be because the dominant woody species such as A. etbaica have coppicing potential after browsing and trampling.

In general, exclosures played a great role in the restoration of degraded lands by improving the vegetation diversity and regeneration status. The least-dominant 
important woody species should be maintained through active restoration rather than left to passive restoration. Future research should be carried out on the composition of non-woody species in these areas and on the ecosystem service value of exclosures. Interaction between local people and exclosure management should also be studied in depth.

Acknowledgments We express my deepest gratitude to Belachew Bogale and Dr. Getu Abebe for their beneficial guidance, unceasing support, and constructive reviews of the study, and also our deepest appreciation to the Regional Forestry Research Directorate (FRD) and Wollo University Forestry Department Staff. We also are very grateful for financial support from the Sekota Dry Land Agricultural Research Center/Amhara Region Agricultural Research Institute (ARARI).

Open Access This article is licensed under a Creative Commons Attribution 4.0 International License, which permits use, sharing, adaptation, distribution and reproduction in any medium or format, as long as you give appropriate credit to the original author(s) and the source, provide a link to the Creative Commons licence, and indicate if changes were made. The images or other third party material in this article are included in the article's Creative Commons licence, unless indicated otherwise in a credit line to the material. If material is not included in the article's Creative Commons licence and your intended use is not permitted by statutory regulation or exceeds the permitted use, you will need to obtain permission directly from the copyright holder. To view a copy of this licence, visit http://creativecommons.org/licenses/by/4.0/.

\section{References}

Adamu H, Tamrat W, Gemedo B (2012) Floristic diversity, regeneration status, and vegetation structure of woodlands in Metema area, Amhara national regional state North-western Ethiopia. J For Res 23(3):91-398

Aerts R, Nyssen J, Haile M (2009) On the difference between "Exclosures" and "Enclosures" in ecology and the environment. J Arid Environ 73:762-763

Anderson MJ (2001) A new method for non-parametric multivariate analysis of variance. Austral Ecol 26:32-46

Atsbha T, Desta AB, Zewdu T (2019) Woody species diversity, population structure, and regeneration status in the Gra-Kahsu natural vegetation, southern Tigray of Ethiopia. Heliyon 5:e0112. https ://doi.org/10.1016/j.heliyon.2019.e01120

Birhane E, Teketay D, Barklund P (2006) Actual and potential contribution of exclosures to enhance biodiversity of woody species in the drylands of Eastern Tigray. J Drylands 1(2):134-147

Birhane E, Teketay D, Pia B (2007) Enclosures to enhance woody species diversity in the dry lands of eastern Tigray, Ethiopia. East Afr J Sci 1(2):136-147

Birhane E, Mengistu T, Seyoum Y, Hagazi N, Putzel L, Rannestad MM, Kassa H (2017) Exclosures as forest and landscape restoration tools: lessons from Tigray Region, Ethiopia. Int For Rev 19:37-50

Descheemaeker K, Nyssen J, Poesen J, Haile M, Muys B, Raes D, Moeyersons J, Deckers J (2006) Soil and water conservation through forest restoration in exclosures of the Tigray highlands. J Drylands 1(2):118-133
Edwards S, Demissew S, Tadesse M, Hedberg I (1969) Flora of Ethiopia and Eritrea: Magnoliaceae to Flacourtiaceae (1st edition). Addis Ababa University and Uppsala University, pp 1-532

Edwards S, Tadesse M, Hedberg I (1995) Flora of Ethiopia and Eritrea. Canellaceae to Euphorbiaceae (1st edition). Addis Ababa University and Uppsala University, pp 1-456

Feyissa A, Teshome S, Mekuria A (2013) Forest carbon stocks and variations along altitudinal gradients in Egdu forest: implications of managing forests for climate change mitigation. Sci Technol Arts Res J 2(4):40-46

Gebregerges T, Tessema ZK, Birhane E (2018) Effect of exclosure ages on woody plant structure, diversity and regeneration potential in the western Tigray region of Ethiopia. J For Res 29(3):697-707

Gebrehiwot T, Veen AVD (2014) The effect of enclosures in rehabilitating degraded vegetation: a case of Enderta district, Northern Ethiopia. Forest Res Open Access 3(4):128

Gotelli NJ, Chao A (2013) Measuring and estimating species richness, species diversity, and biotic similarity from sampling data. Encycl Biodivers 5:195-211

Hedberg I, Edwards S (1989) Flora of Ethiopia: Pittosporaceae to Araliaceae. Asmara and Uppsala University, Addis Ababa, pp $1-659$

Hedberg I, Edwards S, Nemomissa S (2003) Flora of Ethiopia and Eritrea. Magnoliaceae to Flacourtiaceae (1st edition). Addis Ababa University and Uppsala University, Addis Ababa pp 1-532

Hedberg I, Kelbeasa E, Edwards S, Demissew S, Persson E (2006) Flora of Ethiopia and Eritrea: Gentianaceae to Cyclocheilaceae (1st edition). Addis Ababa University and Uppsala University, Addis Ababa, pp 1-690

James JJ, Sheley RL, Erickson T, Rollins KS, Taylor MH, Dixon KW (2013) A systems approach to restoring degraded drylands. J Appl Ecol 50(3):730-739

Kacholi DS (2014) Analysis of structure and diversity of the Kilengwe forest in the Morogoro Region, Tanzania. Int J Biodivers. https:// doi.org/10.1155/2014/516840

Kent M, Cooker P (1992) Vegetation description and analysis: a practical approach. Belhaven Press, London, p 438

Lemenih M, Kassa H (2014) Re-Greening Ethiopia: history, Challenges and Lessons. Forests 5:1896-1909

Magurran AE (2004) Measuring biological diversity. Afr J Aquatic Sci 29(2):285-286

Mekuria, W (2007) Vegetation restoration in area closures: the case of Douga Tembein, central Tigray, Ethiopia. In: Ethiopia: Tropentag 2007 conference on international agricultural research for development, pp 9-11

Mekuria W (2013a) Changes in regulating ecosystem services following establishing exclosures on communal grazing lands in Ethiopia: a synthesis. J Ecosyst. https://doi.org/10.1155/2013/860736

Mekuria W (2013b) Conversion of communal grazing lands into exclosures restored soil properties in the semi-arid lowlands of Northern Ethiopia. Arid Land Res Manag 27:153-166

Mekuria W, Aynekulu E (2013) Exclosure land management for restoration of the soils in degraded communal grazing lands in Northern Ethiopia. Land Degrad Dev 24(6):528-538

Mekuria W, Veldkamp E, Haile M, Gebrehiwot K, Muys B (2009) Effectiveness of exclosures to control soil erosion and local community perception on soil erosion in Tigray, Ethiopia. Afr J Agric Res 4(4):365-377

Mekuria W, Wondie M, Amare T, Wubet A, Feyisa T, Yitaferu B (2018) Restoration of degraded landscapes for ecosystem services in North-Western Ethiopia. Heliyon 4(8):e00764. https:// doi.org/10.1016/j.heliyon.2018.e00764

Mengistu T, Teketay D, Håkan H, Yemshaw Y (2005) The role of enclosures in the recovery of woody vegetation in degraded dryland hillsides of central and northern Ethiopia. J Arid Environ 60:259-281 
Mohammed K, Zebene A, Abayneh D, Mateos M, Yosef M (2015) The role of area closure in the recovery of woody species composition in degraded land and its socio-economic importance in central rift valley area, Ethiopia. Int J Develop Res 5(2):3348-3358

Naidu MT, Kumar OA (2016) Tree diversity, stand structure, and community composition of tropical forests in Eastern Ghats of Andhra Pradesh, India. J Asia-Pacific Biodivers 9(3):328-334

NMSA (National Meteorological Services Agency) (2017) Kombolcha meteorological station, Ethiopia. https://www.ethiomet.gov. et. (Accessed on 26.09.2017)

Schwarz P, Fahey T, McCulloch C (2003) Factors controlling spatial variation of tree species abundance in a forested landscape. Ecology 84(7):1862-1878

Senbeta F, Teketay D (2001) Regeneration of indigenous woody species under the canopies of tree plantations in central Ethiopia. Tropical Ecol 42(2):175-185

Senbeta F, Christine S, Tadese W, Hans JB, Manfred D (2014) Plant diversity, vegetation structure and relationship between plant communities and environmental variables in the Afromontane Forests of Ethiopia. Ethiopia J Sci 37(2):113-130

Shannon CI, Weiner W (1963) The mathematical theory of communication. University of Illinois Press, Urbana, p 111

Simpson EH (1949) Measurement of diversity. Nature 163:688

Teketay D, Keotshephile K, Joseph M, Monica K, John N, Mmusi M, Wellington M (2018) Enhancement of diversity, stand structure and regeneration of woody species through area exclosure: the case of a mopane woodland in northern Botswana. Ecol Process $7(1): 5$

Teshager Z, Mekura A, Abeje E (2018) Woody species diversity, structure and regeneration status in Weiramba forest of Amhara region, Ethiopia: implications of managing forests for biodiversity conservation. J Nat Sci Res 8(5):16-31
Tessema ZK, De Boer WF, Baars RM, Prins HH (2011) Changes in soil nutrients, vegetation structure and herbaceous biomass in response to grazing in a semi-arid savanna of Ethiopia. J Arid Environ 75(7):662-670

Ubuy MH, Gebrehiwot K, Raj AJ (2014) Biomass estimation of exclosure in the Debrekidan watershed, Tigray region, Northern Ethiopia. Int J Agric For 4(2):88-93

Ubuy MH, Tron E, Ole MB, Birhane E (2018) Aboveground biomass models for trees and shrubs of exclosures in the drylands of Tigray, northern Ethiopia. J Arid Environ 156:9-18

Yayneshet T, Eik LO, Moe SR (2009) The effects of exclosures in restoring degraded semi-arid vegetation in communal grazing lands in northern Ethiopia. J Arid Environ 73(4):542-549

Yirdaw E, Tigabu M, Lemenih M, Negash M, Teketay D (2014) Rehabilitation of degraded forest and woodland ecosystems in Ethiopia for sustenance of livelihoods and ecosystem services. In: Katila P, Galloway G, De Jong W, Pacheco P, Mery G (eds) Forests under pressure-local responses to global issues. International Union of Forest Research Organizations, Vantaa, pp 299-313

Yirdaw E, Tigabu M, Monge A (2017) Rehabilitation of degraded dryland ecosystems: review. Silva Fennica 51:32. https://doi. org/10.14214/sf.1673

Zegeye H, Teketay D, Kelbessa E (2006) Diversity, regeneration status and socio-economic importance of the vegetation in the islands of Lake Ziway, south-central Ethiopia. Flora 201(6):483-498

Publisher's Note Springer Nature remains neutral with regard to jurisdictional claims in published maps and institutional affiliations. 